\title{
Development of Antibacterial, Antioxidant, and UV-Barrier Chitosan Film Incorporated with Piper betle Linn Oil as Active Biodegradable Packaging Material
}

\author{
Thuong Thi Nguyen $1,2,3, * \mathbb{C}$, Thu-Thao Thi Nguyen ${ }^{4}$, Thuan Van Tran ${ }^{3}{ }^{\mathbb{D}}$, Lam Van Tan ${ }^{3}$, Luu Thai Danh ${ }^{5}$ and \\ Van Thai Than $6,7, *$ (D)
}

check for

updates

Citation: Nguyen, T.T.; Nguyen, T.-T.T.; Tran, T.V.; Tan, L.V.; Danh, L.T.; Than, V.T. Development of Antibacterial, Antioxidant, and UV-Barrier Chitosan Film Incorporated with Piper betle Linn Oil as Active Biodegradable Packaging Material. Coatings 2021, 11, 351. https://doi.org/10.3390/ coatings11030351

Academic Editor: Maria Jose Fabra

Received: 14 January 2021

Accepted: 5 February 2021

Published: 19 March 2021

Publisher's Note: MDPI stays neutral with regard to jurisdictional claims in published maps and institutional affiliations.

Copyright: (c) 2021 by the authors. Licensee MDPI, Basel, Switzerland. This article is an open access article distributed under the terms and conditions of the Creative Commons Attribution (CC BY) license (https:// creativecommons.org/licenses/by/ $4.0 /)$.
Faculty of Chemistry, University of Science, Ho Chi Minh City 70000, Vietnam

Vietnam National University, Ho Chi Minh City 70000, Vietnam

3 NTT Hi-Tech Institute, Nguyen Tat Thanh University, Ho Chi Minh City 70000, Vietnam; tranuv@gmail.com (T.V.T.); lvtan@ntt.edu.vn (L.V.T.)

4 Faculty of Chemical Technology, Ho Chi Minh City University of Food Industry, Ho Chi Minh City 70000, Vietnam; thuthaonguyen743@gmail.com

5 College of Agriculture, Can Tho University, Can Tho 900000, Vietnam; 1tdanh@ctu.edu.vn

6 Faculty of Biotechnology, Chemistry and Environmental Engineering, PHENIKAA University, Yen Nghia, Ha Dong, Hanoi 12116, Vietnam

7 Phenikaa Research and Technology Institute (PRATI), A\&A Green Phoenix Group JSC, No. 167 Hoang Ngan, Trung Hoa, Cau Giay, Hanoi 11313, Vietnam

* Correspondence: nthithuong@ntt.edu.vn (T.T.N.); thai.thanvan@phenikaa-uni.edu.vn (V.T.T.); Tel.: +84-9850-90912 (T.T.N.); +84-9757-16090 (V.T.T.)

Abstract: This study aims to introduce the antibacterial and antioxidant activities of the Piper betle Linn oil (PBLO) into chitosan film (pCS), named as pCS-PBLO film. The morphology, structure, and properties of the pCS-PBLO film, along with the PBLO concentration between $0.4 \%$ and $1.2 \%$ $(v / v)$, were determined. The film surface became rough and heterogeneous with the addition of PBLO, which directly influenced on mechanical strength of the resultant film. The addition of the PBLO did not affect thermal stability but significant effect on flexibility and mobility of the film. Importantly, the film enhanced the UV-protective property and antioxidant activity as incorporated-PBLO. Moreover, the resulting film revealed the great inhibition efficiency against the negative-gram (E. coli, P. aeruginosa, and S. typhi) and positive-gram (S. aureus) bacteria based on phenolic compounds, such as the acetyleugenol, eugenol, 4-allyl-1,2-diacetoxybenzen, and chavicol acetate in PBLO components. In particular, the pCS-PBLO film may extend the shelf life of king oranges up to two weeks at $25^{\circ} \mathrm{C}$ that is longer as compared to the uncoated sample and coated with chitosan alone. These results suggest that the pCS-PBLO film can be used as environmental-friendly and effective food packaging material in the future.

Keywords: antibacterial activity; antioxidant activity; chitosan film; Piper betle Linn oil; UV-barrier property

\section{Highlights}

Successful development of chitosan film incorporated with piper betel Linn oil as active food packaging material

The pCS-PBLO film possessed thermal stability and stretchability

Impressive UV-barrier function was found in the pCS-PBLO film

The pCS-PBLO film showed antibacterial and antioxidant activities

\section{Introduction}

Petroleum-based plastics are one of the main contributors to serious environmental pollution due to their un-degradable characters. It was found that thousands of marine 
wildlife were yearly killed by ingesting plastic-based pollutants or getting entangled [1]. To address these problems, the recent development of biodegradable and environmentalfriendly materials as interesting alternatives to conventional plastics has been paid much attention in food packaging area. Biodegradable plastics were abundantly developed from polysaccharides such as chitosan, chitin, starch, cellulose, pectin [2]. In response to increasing people's standard of living and productivity growth in agricultural production, active packaging produced by the incorporation of antibacterial and antioxidant agents has become equally crucial interests, when food-borne pathogen is the major cause of food deterioration limiting the supply of nutritious and security foods $[3,4]$. The combination of natural materials to produce environmental-friendly and active coating to prolonging the shelf life of food, has been developed and considered as a favorable technology in food preservation $[5,6]$.

Piper betle Linn, a traditional herb from Piperaceae family, is widely found in India, Indonesia, Malaysia, Philippines, Sri Lanka, and other Southeast Asian and East African countries [7]. The major components of Piper betle Linn is complex mixture of polyphenols, flavonoids, tannins, and polysaccharides [8]. Phytochemical compounds such as hydroxy chavicol, 4-chromanol, and eugenol were found consistence in India betle leaves which offered great antioxidant, anti-inflammatory, antibacterial, and antifungal properties [9]. The betle essential oil has been also reported to be the potential sources to produce ayurvedic medicine and herbal products due to containing chavibetol, caryophyllene, and methyl eugenol components [10]. Furthermore, Piper betle Linn oil was also known as food additive for the preservation and extension of the shelf life of dry fruits, spices, and areca nut [11].

Chitosan is a product from the deacetylation of chitin which is abundantly obtained from the natural sources such as the shells of crustaceans, arthropod, and fungi [12]. Chitosan possesses antibacterial, antifungal, biodegradable, and biocompatible characters because it's structure composed of $\beta-1,4-$ linked glucosamine and N-acetylglucosamine [13]. In general, chitosan contains the charged groups which can interact with the peptidoglycans in the microorganism wall causing the leakage of intracellular electrolytes and cell death $[14,15]$. Interestingly, chitosan is recognized as food additive as listed in listed in Generally Recognized as Safe (GRAS) by US food and Drug Administration in 2013 and thus it is ideally suitable for packaging material in directly contacting with foods. Furthermore, the excellent film-forming property of chitosan makes it to become ideal candidate for active packaging area. Recently, much effort on the introduction of essential oils into chitosan film to produce packaging film possessing antibacterial and antioxidant function has been reported in different studies. The addition the chitosan film with the cinnamon oil (CO) [at concentration of $0.4-2 \%(v / v)$ ] displayed antibacterial activity and moisture barrier property, in which the low flexibility and mobility of blend film with further increasing $\mathrm{CO}$ content was a negative mark [16]; the Zataria multiflora Boiss oil showed antioxidant activity and water barrier property, however the film displayed poor mechanical behavior [17]; the basil essential oil [at concentration of $0.1-0.5 \%(v / v)$ ] enhanced antibacterial activity and water vapor barrier property of resultant film but decreased in mechanical property of the film [18]; the Perilla frutescens (L.) Britt. essential oil [at concentration of $0.2-1 \%$ $(v / v)]$ imparted water barrier and antibacterial function but also revealed a decrease in mechanical property of the film [19]; the Eucalyptus globulus essential oil [at concentration of 1-4\% $(v / v)$ ] endowed both antibacterial and antioxidant activities [20]; and in a more recent work, the anise (Pimpinella anisum L.) essential oil [at concentration of $0.5-2 \%$ $(v / v)$ ] enhanced mechanical property, water barrier property, and antibacterial activity [21]; and the Apricot (Prunus armeniaca) kernel essential oil [at concentration of $0.25-2 \%(v / v)$ ] enhanced water barrier, antibacterial, antioxidant, and antifungal property [22].

In our previous finding, the Piper betel Linn leaf extract (PBLLE) was successfully introduced into chitosan film uninvolving plasticizer to impart outstanding antibacterial activity, antioxidant activity, and good resistance to water vapor permeation to prepared films [23]. Herein, we found that the utilization of piper betel Linn oil (PBLO) to chitosan film with glycerol-based plasticizer induced different behaviors in bioactivity and physical 
property of resultant film as compared to the addition of PBLLE because of high hydrophobicity of PBLO. Interestingly, the light of present work was high transparent of film made from chitosan and PBLO in visible region as compared to chitosan film containing PBLLE in dark brownish which significantly affected to see-through property important for food packaging material as customer want to see packaged product before buying. Bedsides to this, the combination of nontoxic components including chitosan and Piper betel Linn oil is considered to be safe material for food packaging.

\section{Experimental}

\subsection{Materials}

Chitosan (DD 75-85\%, and $\mathrm{M}_{\mathrm{W}} \sim 50-190 \mathrm{kDa}$ ), glycerol ( $\geq 99.5 \%$ ), Folin-Ciocalteu's phenol reagent $(\geq 98 \%)$, sodium carbonate $(\geq 99 \%)$, sodium chloride $(\geq 99 \%)$, 2,2-diphenyl1-picrylhydrazyl (97\%), and gallic acid ( $\geq 98 \%)$ were supplied by Sigma-Aldrich (Missouri, MO, USA). Ethanol (99.7\%), Tween 80 (98\%) and methanol (99.7\%) were purchased from Sinopharm Chemical Reagent Co. Ltd. (Shanghai, China). Piper betle Linn leaf was collected from Hau Giang province, Vietnam and extracted oil through hydrodistillation, followed by the store at $-2{ }^{\circ} \mathrm{C}$ until use. Bacterial strains including Staphylococcus aureus (S. aureus) NRRL B-313, Pseudomonas aeruginosa (P. aeruginosa) NRRL B-14781, Escherichia coli (E. coli) NRRL B-409, and Salmonella typhimurium (S. typhimurium) YS1646 were provided by Institute of Tropical Biology, Vietnam Academy of Science and Technology (Ho Chi Minh, Vietnam).

\subsection{Analyses of $P B L O$}

Chemical composition of PBLO was determined by using GC Agilent $6890 \mathrm{~N}$ instrument (California, CA, USA) equipped with MS 5973 inert and HP5-MS column. The head column pressure was 9.3 psi and helium worked as the carrier gas with velocity of $1 \mathrm{~mL} / \mathrm{min}$. Before testing, $25 \mu \mathrm{L}$ of PBLO was mixed in $1 \mathrm{~mL}$ of $\mathrm{n}$-hexane and further dehydrated by $\mathrm{Na}_{2} \mathrm{SO}_{4}$. The injection temperature was set at $250{ }^{\circ} \mathrm{C}$ and split injection in the ratio of 1:100. Thermal profiles were set up as follows: the initial column temperature at $50{ }^{\circ} \mathrm{C}$ for $2 \mathrm{~min}$, continued up to $80^{\circ} \mathrm{C}$ at velocity of $2{ }^{\circ} \mathrm{C} / \mathrm{min}$, continually increasing to $150{ }^{\circ} \mathrm{C}$ at velocity of $5{ }^{\circ} \mathrm{C} / \mathrm{min}$, and followed to increase to $300^{\circ} \mathrm{C}$ at velocity of $20^{\circ} \mathrm{C} / \mathrm{min}$ for $5 \mathrm{~min}$. The individual compound was identified and confirmed by comparing to those of available library data from GC/MS system.

\subsection{Preparation of $p C S-P B L O$ films}

Chitosan solution was produced by dissolving $1 \mathrm{~g}$ of chitosan powder in $100 \mathrm{~mL}$ of aqueous acetic acidic solution $(1 \%, v / v)$. The solution was magnetically stirred at $800 \mathrm{rpm}$ and room temperature (at around $27^{\circ} \mathrm{C}$ ) for $24 \mathrm{~h}$ to dissolve completely solids. Glycerol $(30 \%, w / w)$ was then added into chitosan solution with the function of plasticizer. Subsequently, the PBLO was added into plasticized chitosan solution at different volume ratio $[0.4 \%, 1 \%$, and $1.2 \%(v / v)]$ before adding $0.2 \%(w / v)$ of Tween 80 as an emulsifier. Finally, film-forming solution was casted on the $20 \mathrm{~cm} \times 20 \mathrm{~cm}$ plastic mold and further dried at $40{ }^{\circ} \mathrm{C}$ for $48 \mathrm{~h}$. After drying, the chitosan-based blend films were peeled off and kept at $25^{\circ} \mathrm{C}$ for further analyses. The control chitosan film was denoted as pCS and chitosan films containing PBLO were remarked as pCS-0.4PBLO, pCS-1PBLO, and pCS-1.2PBLO with respect to incorporated PBLO content at $0.4 \%, 1 \%$, and $1.2 \%(v / v)$. The thickness of films was controlled by taking equal volume in film fabrication process to ensure ignorable variation and thickness values were recorded at $0.053 \pm 0.002 ; 0.055 \pm 0.003 ; 0.064 \pm 0.003$; and $0.078 \pm 0.004$, respectively for pCS, pCS-0.4PBLO, pCS-1PBLO, and pCS-1.2PBLO.

\subsection{Film Characterization}

The surface morphology of the as-prepared films was recorded using scanning electron microscope (SEM) on JSM-IT200 equipment (Massachusetts, MA, USA). The attenuated total reflection (ATR)/Fourier transform infrared (FTIR) (ATR/FTIR) spectra of 
the as-prepared films were determined using a JASCO FT/IR-6600 instrument (JASCO International Co., Tokyo, Japan) in the wavenumber ranged from $4000-500 \mathrm{~cm}^{-1}$. The thermo-stability of the as-prepared films was determined using the thermogravimetric analyses (TGA) and derivative thermogravimetric (DTG) on a TGA model Q500 V20.10 Build 36 (TA Instruments, Hüllhorst, Germany) by a temperature program of $27-800{ }^{\circ} \mathrm{C}$ with heating rate of $10^{\circ} \mathrm{C} / \mathrm{min}$. The crystal structure of the as-prepared films was determined using X-ray diffraction (XRD) on a Bruker D8 Advance powder diffractometer (Bruker AXS GmbH, Berlin, Germany) with $\mathrm{Cu}-\mathrm{K} \alpha$ radiation source and $2 \theta$ range of $2-60^{\circ}$ with $0.2 \mathrm{~s} / \mathrm{step}$. The mechanical behavior of the as-prepared films was measure on AG-Xplus Series Precision Universal Testers following to ASTM-D882 standard [24] with the size film of $15 \mathrm{~mm} \times 100 \mathrm{~mm}$ and gauge length of $50 \mathrm{~mm}$ and crosshead speed of $10 \mathrm{~mm} / \mathrm{min}$ at room temperature (at around $27^{\circ} \mathrm{C}$ ). The transmittance of the as-prepared films was recorded on UV-1800 UV/Visible Scanning Spectrophotometer (Shimadzu Scientific Instruments Inc., Kyoto, Japan) in wavelength range of $190-800 \mathrm{~nm}$.

Swelling degree (SD) was performed based on the method previously described [25]. Five pieces $(2 \mathrm{~cm} \times 2 \mathrm{~cm})$ of film were initially dried at $70{ }^{\circ} \mathrm{C}$ for $24 \mathrm{~h}$ and weighted to get dry weight denoted as $\mathrm{m}_{1}$. Then, the dried pieces of film were soaked in $30 \mathrm{~mL}$ of distilled water for $24 \mathrm{~h}$ at room temperature $\left(27^{\circ} \mathrm{C}\right)$. For next step, the pieces of film were separated from water and removed the residual surface water using tissue paper and further weighted $\left(m_{2}\right)$. The SD $(\%)$ was calculated by following equations:

$$
\mathrm{SD}(\%)=\frac{m_{2}-m_{1}}{m_{1}} \times 100 \%
$$

\subsection{Bacterial Inhibition Test}

The antibacterial activities of the pCS and pCS-PBLO films were tested using the agar diffusion and liquid incubation methods as previously descriptions $[25,26]$. For the agar diffusion tests, a $100 \mu \mathrm{L}$ (an approximately titer of $2 \times 10^{6}$ colony forming units per $\mathrm{mL}, \mathrm{CFU} / \mathrm{mL}$ ) of each bacterial strain, including the S. aureus, S. typhimurium, E. coli, and P. aeruginosa, was spread onto the LB agar plates (Sigma-Aldrich, Missouri, MO, USA) in triplicate. A $1-\mathrm{cm}^{2}$ slide of each pCS and pCS-PBLO films were then added onto midpoint of the plates (Supplementary Figure S1). Subsequently, the plates were incubated at $37^{\circ} \mathrm{C}$ for $24 \mathrm{~h}$. The inhibition zone diameters were measured with a ruler.

For the liquid incubation tests, only the E. coli strain was used. A 2- $\mathrm{cm}^{2}$ slide of each pCS and pCS-PBLO films was added into the tubes containing $2 \mathrm{~mL}$ of the LB medium. The $5 \%(v / v)$ of bacterial suspension at density of $2 \times 10^{8} \mathrm{CFU} / \mathrm{mL}$ was added into the tubes. The tubes were incubated in sharking incubator at $37^{\circ} \mathrm{C}$ and $200 \mathrm{rpm}$. The medium was collected at different incubated times of $0,4,8,11$, and $24 \mathrm{~h}$, and direct spread onto the agar plates in triplicate to evaluate the bacterial viability.

$$
\mathrm{A}\left(\frac{\mathrm{CFU}}{\mathrm{mL}}\right)=\frac{\mathrm{N}}{3} \times f
$$

(where: A, total colonies in $1 \mathrm{~mL}$ of sample; $\mathrm{N}$, total colonies in three agar plates; and $f$, the dilution factor).

\subsection{Antioxidant Test}

The antioxidant activity of chitosan solution with and without PBLO was determined using 2,2-diphenyl-1-picrylhydrazyl free radical (DPPH·) method previously described by Brand-Williams et al. [27]. Initially, the chitosan-PBLO solutions were diluted in distillated water to obtain the different concentration seri (500-32.25 $\mu \mathrm{g} / \mathrm{mL})$. The diluted sample solution $(1 \mathrm{~mL})$ was added into $1 \mathrm{~mL}$ of $0.3 \mathrm{mM} \mathrm{DPPH}$. methanol solution and further well-vortexed for $7 \mathrm{~s}$ before dark-incubating for $60 \mathrm{~min}$ at ambient temperature $\left(27^{\circ} \mathrm{C}\right)$. 
After dark-incubated, the UV-Vis absorbance of mixture solution was measured at $517 \mathrm{~nm}$. The scavenge efficiency to DPPH free radical was calculated in the following equation:

$$
\text { Scavenge efficiency }(\mathrm{SE} \%)=\frac{\mathrm{OD}_{\mathrm{c}}-\mathrm{OD}_{\mathrm{t}}}{\mathrm{OD}_{\mathrm{c}}} \times 100
$$

(where $\mathrm{OD}_{\mathrm{c}}$ and $\mathrm{OD}_{\mathrm{t}}$ are respectively the absorbance of $0.3 \mathrm{mM} \mathrm{DPPH}$. methanol solution and the chitosan-PBLO solution).

Antioxidant activity of PBLO containing chitosan film was evaluated through $\mathrm{IC}_{50}$ $(\mu \mathrm{g} / \mathrm{mL})$ which was determined from the plot of working sample concentration versus $\mathrm{SE} \%$. The experiments were replicated in triplicates to get an average $\mathrm{IC}_{50}$ parameter for each composition.

\subsection{Surface Tension, Work of Adhension, and Spreading Coefficient}

The coating efficiency of the coating solution was evaluated by the work of adhesion and spreading coefficient due to contact angle measurement of coating liquids over orange skin [28]. Surface tension of coating solution and contact angle of all chitosan solution with and without PBLO over orange skin was determined by using a Theta Optical Goniometer (Jersey, NJ, USA). The adhesion and spreading coefficient were calculated according to the Wenzel equation [29] as follows:

$$
\begin{gathered}
\text { Work of adhesion }=\gamma_{1}(1+\cos \theta) \\
\text { Spreading coefficient }=\gamma_{1}(\cos \theta-1)
\end{gathered}
$$

where $\gamma_{1}$ and $\theta$ are respectively the surface tension of coting solution and the contact angle of the film coating on the orange skin.

\subsection{Coating of King Oranges}

King oranges were pre-treated by washing with distilled water and further blow-dried under a fan at ambient temperature $\left(27^{\circ} \mathrm{C}\right)$. The king oranges were coated by chitosan and chitosan-PBLO solution using the pressure-spraying method. The uncoated oranges were used as control sample. All coated samples were then stored at $25^{\circ} \mathrm{C}$ and daily evaluated the appearance changes for 2 weeks.

\section{Results and Discussion}

\subsection{Chemical Composition of Piper betle Linn oil}

The volatile profile of Piper betle Linn oil (PBLO) was determined using GC-MS (Table 1). Thirty-eight various compounds were composed $98 \%$ of total oil. It can be seen that the phenolic components abundantly accounted for highest area percentage (48\%) of total oil, including acetyleugenol (17.51\%), eugenol (14.29\%), 4-allyl-1,2-diacetoxybenzen $(10.92 \%)$, chavicol acetate $(3.00 \%)$, 3-allyl-6-methoxyphenol (1.82\%), and 4-allylphenyl acetate $(0.42 \%)$. These results indicated that the eugenol and it's derive were main components in PBLO which were possibly used as natural antibacterial and antioxidant agents in food packaging area. Similar finding was found in Piper betle var. magahi oil collected from Varanasi, India reported by Prakash et al. [11] mainly consisted of phenolic compounds such as eugenol (63.39\%), acetyleugenol (14.05\%), 4-allyl-1,2-diacetoxybenzen $(0.13 \%)$, and chavicol $(0.55 \%)$ meanwhile this variety only contained eugenol $44.14 \%$ and chavicol $1.52 \%$ when it was harvested from West Bengal, India [30]. The differences in phenolic content and types came from the ecological and geographical regions, age of leaves, harvesting season, drying, and extraction conditions [31]. 
Table 1. Chemical composition of Piper betle Linn. leaf oil.

\begin{tabular}{|c|c|c|c|}
\hline No. & Retention Time (min) & Compound Name & Area Percent ( $\%)$ \\
\hline 1 & 7.261 & $\alpha$-Pinene & 1.051 \\
\hline 2 & 7.837 & Camphene & 0.314 \\
\hline 3 & 9.081 & $\beta$-Pinene & 0.171 \\
\hline 4 & 11.862 & Eucalyptol & 1.376 \\
\hline 5 & 16.15 & $\beta$-Linalool & 0.36 \\
\hline 6 & 26.481 & $\delta$-Elemene & 0.364 \\
\hline 7 & 26.847 & Chavicol acetate & 3.004 \\
\hline 8 & 27.088 & 4-Allylphenyl acetate & 0.422 \\
\hline 9 & 27.642 & Eugenol & 14.209 \\
\hline 10 & 27.673 & Copaene & 3.098 \\
\hline 11 & 27.746 & 3-Allyl-6-methoxyphenol & 1.824 \\
\hline 12 & 27.977 & Geraniol acetate & 1.19 \\
\hline 13 & 28.227 & $\beta$-Elemene & 2.343 \\
\hline 14 & 28.928 & $\alpha$-Bergamotene & 0.952 \\
\hline 15 & 29.043 & Caryophyllene & 9.107 \\
\hline 16 & 29.315 & $\beta$-copaene & 0.486 \\
\hline 17 & 29.514 & $\alpha$-Bergamotene & 0.711 \\
\hline 18 & 29.597 & Aromadendrene & 0.794 \\
\hline 19 & 30.016 & $\alpha$-Caryophyllene & 1.732 \\
\hline 20 & 30.152 & $\beta$-Farnesene & 0.383 \\
\hline 21 & 30.695 & $\gamma$-Muurolene & 6.015 \\
\hline 22 & 30.81 & Germacrene D & 3.945 \\
\hline 23 & 30.904 & $\begin{array}{c}\text { 2-Isopropenyl-4a,8-dimethyl } \\
1,2,3,4,4 \mathrm{a}, 5,6,7 \text {-octahydronaphthalene }\end{array}$ & 0.998 \\
\hline 24 & 31.208 & $\beta$-Cyclogermacrane & 3.964 \\
\hline 25 & 31.333 & $\alpha$-Muurolene & 1.053 \\
\hline 26 & 31.542 & $\beta$-Bisabolene & 1.34 \\
\hline 27 & 31.678 & $\gamma$-Cadinene & 0.767 \\
\hline 28 & 31.908 & $\beta$-Cadinene & 3.361 \\
\hline 29 & 32.086 & Acetyleugenol & 17.511 \\
\hline 30 & 32.327 & $\alpha$-Calacorene & 0.777 \\
\hline 31 & 32.902 & Palustrol & 0.24 \\
\hline 32 & 33.247 & Globulol & 0.589 \\
\hline 33 & 33.404 & Viridiflorol & 0.446 \\
\hline 34 & 33.602 & cis-Eudesm-6-en-11-ol & 0.228 \\
\hline 35 & 33.916 & Junenol & 0.151 \\
\hline 36 & 34.073 & 1,10-Diepicubenol & 0.33 \\
\hline 37 & 34.366 & 4-Allyl-1,2-diacetoxybenzene & 10.922 \\
\hline 38 & 34.543 & $\alpha$-Cadinol & 0.948 \\
\hline
\end{tabular}

\subsection{ATR/FTIR Analyses}

ATR/FTIR spectroscopy was used for the purpose of identifying chemical functional groups and determining possible interaction between components in polymeric blend. The spectrum of film made from chitosan alone presents an absorption band in the range of 3624-3012 $\mathrm{cm}^{-1}$ due to the overlapping of $\mathrm{O}-\mathrm{H}$ and $\mathrm{N}-\mathrm{H}$ stretching vibration (Figure 1) [32]. The $\mathrm{C}-\mathrm{H}$ antisymmetric and symmetric stretching vibrations of $-\mathrm{CH}_{2}$ groups were recorded at $2873 \mathrm{~cm}^{-1}$ [33]. The characteristic chitosan signs were observed at $1650 \mathrm{~cm}^{-1}$ belonging to $\mathrm{C}=\mathrm{O}$ stretching vibration in amide-I, $1532 \mathrm{~cm}^{-1}$ corresponding to C-N stretching vibration composed in amide-II and N-H bending vibration, and $1400 \mathrm{~cm}^{-1}$ (HN-CO stretching vibration in amide-III) [32,34]. Meanwhile the sharp peak at $1020 \mathrm{~cm}^{-1}$ was related to $\mathrm{C}-\mathrm{O}$ stretching vibration [34]. It was found that appreciable changes in chitosan ATR-FTIR spectrum by the addition of PBLO. For instance, the absorption band at $3624-3012 \mathrm{~cm}^{-1}(\mathrm{O}-\mathrm{H}$ and $\mathrm{N}-\mathrm{H}$ stretching vibration) became weaker and more flatted by the addition of PBLO. The decrease in the peak intensity at $1533 \mathrm{~cm}^{-1}$ corresponding to $\mathrm{C}-\mathrm{N}$ stretching vibration and $1402 \mathrm{~cm}^{-1}$ (NH-CO stretching vibration) by the addition of PBLO along with the significant evolution of shoulder at $1584 \mathrm{~cm}^{-1}$ due to the aromatic 
ring vibration of phenolic compounds [33]. Furthermore, the absorption band at $1020 \mathrm{~cm}^{-1}$ (corresponding to $\mathrm{C}-\mathrm{O}$ stretching vibration) in the film formulation made from chitosan and PBLO shifted to higher frequency region and became more intense and compared to those in control chitosan spectrum when PBLO abundantly contained C-O groups in structure of phenolic compounds. These changes were likely ascribed to the hydrogen-bonding interaction between $\mathrm{O}-\mathrm{H}$ and $\mathrm{N}-\mathrm{H}$ groups in chitosan and hydroxyl of phenolic compound in PBLO [33]. Murat Kaya et al. [33] also found the possible hydrogen interactions arising between film functional groups and Berberis crataegina's seed oil evidenced by the slight shift in the $\mathrm{C}-\mathrm{O}$ stretching vibration peak to a higher frequency region when seed oil was incorporated into chitosan.

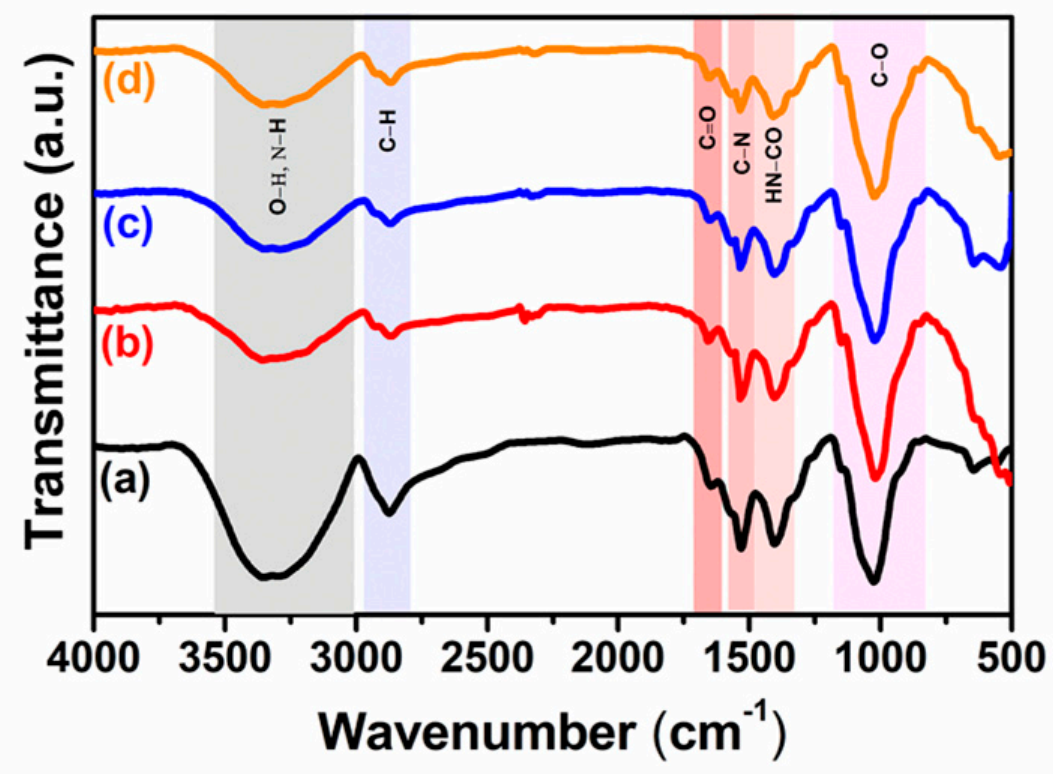

Figure 1. The ATR/FTIR analyses of (a) pCS, (b) pCS-0.4PBLO, (c) pCS-1PBLO, and (d) pCS-1.2PBLO.

The ATR/FTIR results indicated the existence of inter-molecular interaction between functional groups in PBLO and chitosan, which could be expected to diminish oil release into environment and thus allowing maintaining antibacterial and antioxidant activity of blend films during food protection.

\subsection{XRD Analyses}

Possible structural changes in chitosan network with the addition of PBLO were confirmed by XRD (Figure 2). The film made from chitosan alone reveals characteristic peaks at $11.4^{\circ}$ and $18.1^{\circ}$, which are closely related to anhydrous and hydrated crystalline $[7,35]$, and a typical fingerprint at $20.8^{\circ}$ attributed to amorphous state of chitosan [36,37]. The disappearance of crystal peaks at $11.4^{\circ}$ and $18.1^{\circ}$ and the increase in diffraction intensity at $20.8^{\circ}$ as the addition of $0.4 \%(v / v)$ and $1.2 \%(v / v)$ PBLO imply a decrease in crystallinity of blend film. It is likely suggested that inter-molecular interaction between phenolic groups in PBLO and chitosan functional groups hinder and disturb intra-molecular interaction between chitosan chains resulting in the predominance of amorphous region [34]. Besides to this, the new pronounced diffraction peak was identified at $14.4^{\circ}$ with $1.2 \%(v / v)$ PBLO addition, probably indicating that such inter-molecular interactions exert the rearrangement in polymeric network to generate newly ordered structure. The similar behavior in the reduction in crystalline was documented in chitosan consisted of polyphenols from thinned young apple [37]. However, re-evolution of the crystalline peaks at $11.4^{\circ}$ and $18.1^{\circ}$ with higher diffraction intensity in chitosan film containing $1 \%(v / v)$ PBLO is still unclear, it is likely to suggest that the position of original ordered chains in control chitosan are replaced by a large amount of crosslinking network between chitosan and PBLO. It can be 
therefore concluded that the addition of PBLO may convert semi-crystalline in chitosan film toward more amorphous structure, which significant affect to mechanical behavior of the blend film in further investigation.

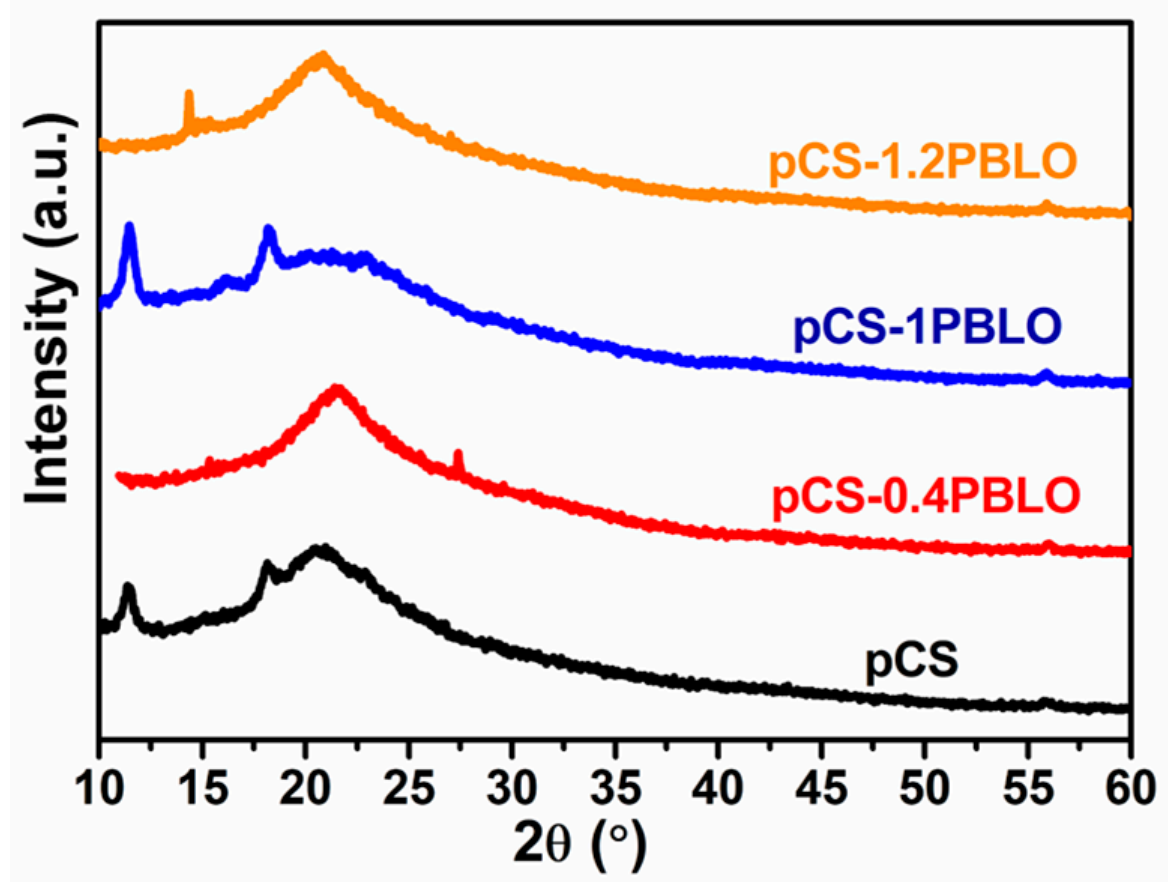

Figure 2. XRD analyses of pCS, pCS-0.4PBLO, pCS-1PBLO, and pCS-1.2PBLO.

\subsection{Thermo-Stability}

TGA and DTG analyses were utilized for the purpose of investing the thermal stability of film made from chitosan alone and containing PBLO. As seen in TGA curves (Figure 3a), the control chitosan film presents three-stage decomposition. The first stage at $50-150{ }^{\circ} \mathrm{C}$ was due to the vaporization of adsorbed water on the film surface $\left(50-80^{\circ} \mathrm{C}\right)$ and residual acetic acid $\left(80-150{ }^{\circ} \mathrm{C}\right)[19,38]$. The decomposition of glycerol-based plasticizer occurred at $150-250{ }^{\circ} \mathrm{C}$ [19]. The main degradation stage at $250-360{ }^{\circ} \mathrm{C}$ with $43 \%$ weight loss (Table S1) was attributed to the saccharide ring dehydration and decomposition of chitosan backbone [19]. In case of chitosan with PBLO, there are three steps of decomposition were documented at $50-150{ }^{\circ} \mathrm{C}, 150-360{ }^{\circ} \mathrm{C}$, and $360-450{ }^{\circ} \mathrm{C}$. It should be noticed that the decomposition of glycerol is negligible in the TGA curves of blend films and the newly decomposition stage not found in chitosan alone appears at $400-450{ }^{\circ} \mathrm{C}$ due to the decomposition of aromatic compounds in PBLO and surfactants [34,38,39]. The difference in thermal behavior of chitosan film with and without PBLO was pronouncedly observed from DTG profile. In details, the decomposition peak of chitosan backbone was recorded at $296{ }^{\circ} \mathrm{C}$ and $284^{\circ} \mathrm{C}$ for control chitosan and pCS-PBLO film, respectively. This result indicated that the thermal stability of chitosan film slightly decreased by the addition of PBLO. More interesting, it was not found the PBLO own degradation peak. This was likely pointed that PBLO was well-embedded in blend film due to the inter-molecular interaction between phenolic compounds and chitosan functional groups resulting in good protective effect and preventing separate decomposition of PBLO. 
(a)
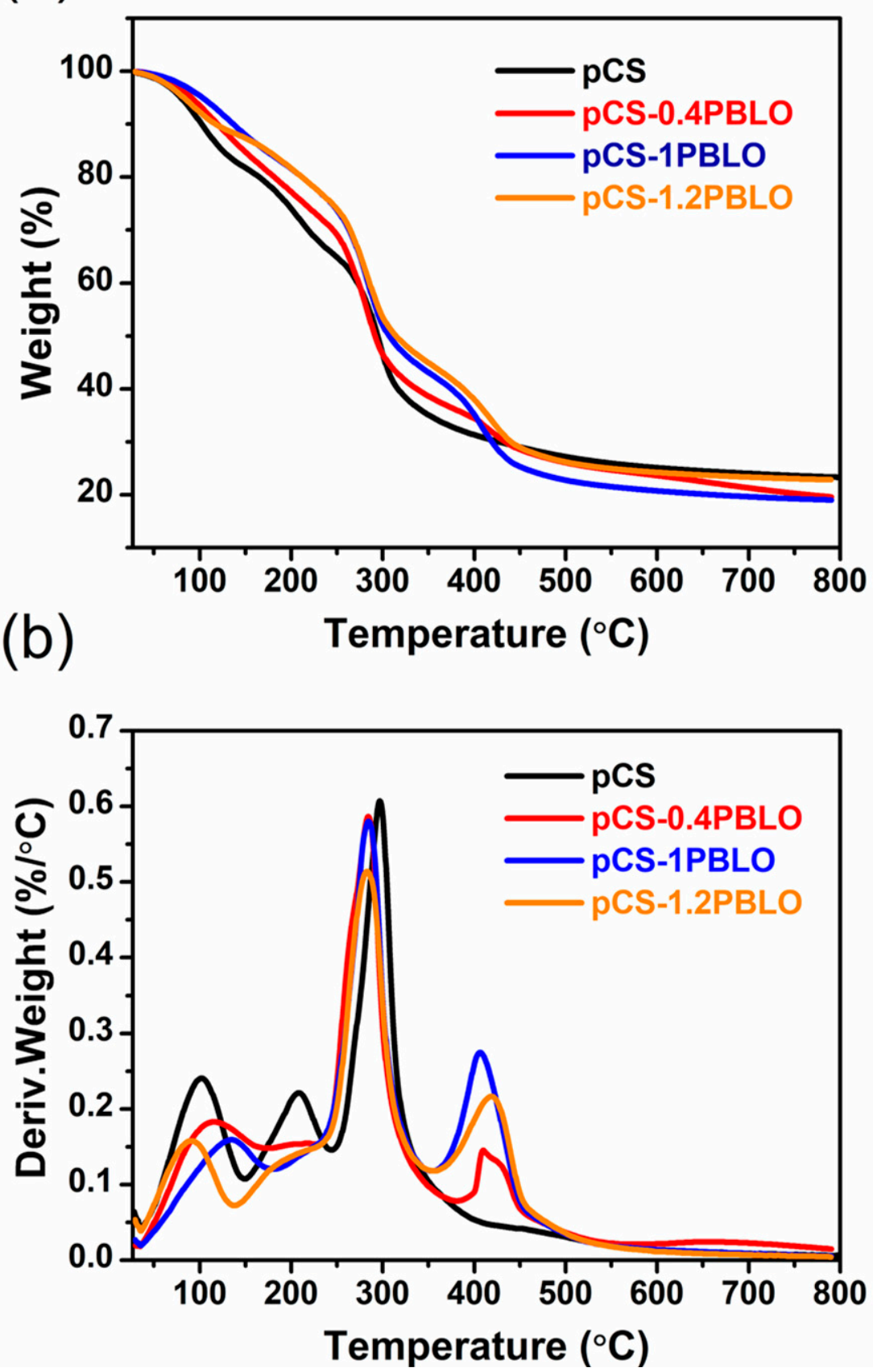

Figure 3. (a) TGA and (b) DTG profiles of pCS, pCS-0.4PBLO, pCS-1PBLO, and pCS-1.2PBLO.

\subsection{The Surface Morphology}

The surface images at micro level of film formulation made from chitosan alone and containing 0.4-1.2 \% $(v / v)$ PBLO are observed in Figure 4. Herein, glycerol was additionally used as plasticizer for all the films and the successful film formation for all applied formulations was obtained as expected. The control chitosan film without PBLO displayed uniform, smooth, homogeneous appearance without cracks and fractures, indicating compact and continuous structure. Meanwhile the film made from blend of chitosan and PBLO presented the rough and heterogeneous surface with the appearance of spherical-like droplets, resulting in discontinuities in blend film that may affect to weak fracture resistance of film. The existence of spherical-like droplets indicated the dispersion of lipid droplets on the surface of resulting films. However, the spherical-like droplets 
were not found on the surface of chitosan film incorporated with Piper betle Linn leaf extract $[23,40]$. Similar findings were found in chitosan film containing $0.4-1.2 \%(w / v)$ Origanum vulgare L. oil [30], and 1-4\% (v/v) Eucalyptus globulus oil [20], when spherical oil droplets tended to separate and center at the upper surface of film, likely resulted from the traction force caused by chitosan matrix during drying step. At lower PBLO content $(0.4 \%, v / v)$, lipid droplets were scarcely observable since they abundantly concentrated on the surface of film with small droplet size. As increasing PBLO concentration to 1\% $(v / v)$, droplet size slightly enlarged and became visible. However, the film surface became more heterogeneous when some spherical-like droplets were embedded and trapped in the polymeric network. The slight increase in droplet size may due to the fact that flocculation and coalescence occurred at higher lipid content [41]. Although droplet size of lipids was lower, the surface of chitosan film containing 1.2\% $(v / v)$ PBLO become more homogeneous as compared to that in inclusion of $0.4 \%(v / v)$ and $1 \%(v / v)$ PBLO. The decrease in lipid size likely due to well-embedded oil droplets in polysaccharide matrix resulting in the change in the shape of lipid droplets. This observation was coincident with what was seen gelatin-chitosan containing Origanum vulgare L. essential oil (OEO) as higher droplet size was found in film incorporated with $0.8 \%(w / v)$ OEO than that in $0.4(w / v)$ and $1.2(w / v)$ incorporated-OEO [42].
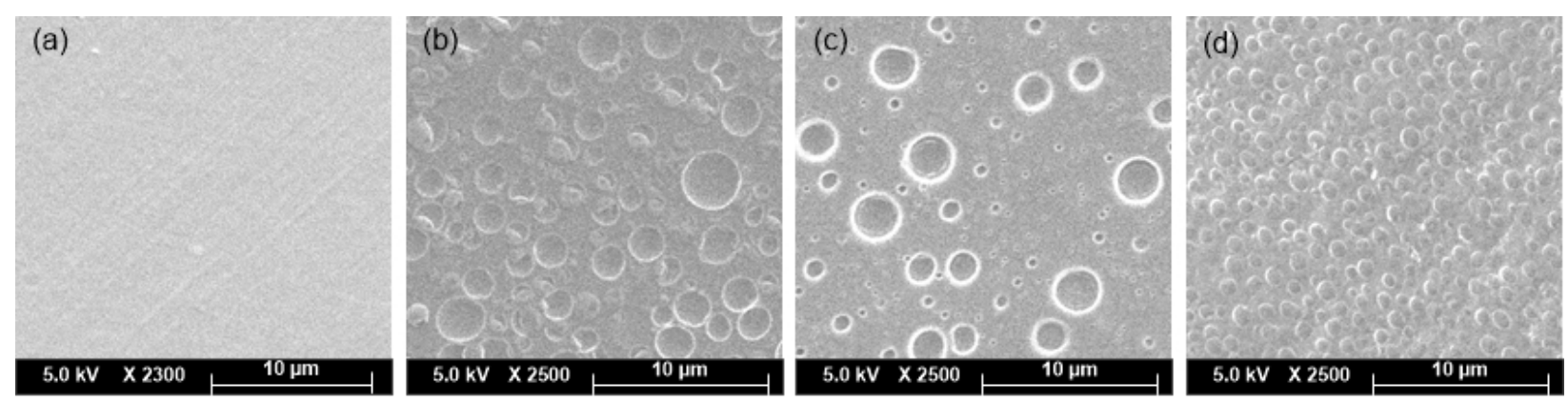

Figure 4. SEM images of (a) pCS, (b) pCS-0.4PBLO, (c) pCS-1PBLO, and (d) pCS-1.2PBLO.

\subsection{UV-Protective Property}

The high transparent and see-through property are important for food packaging material because it easily attract customer who want to see packaged product before buying. The UV barrier property is of great benefit to protect food preventing photo-oxidation and degradation of vitamin and other photosensitizers [43]. The light transmittance in UV-Vis of 200-800 nm for chitosan-based films is displayed in Figure 5. The film made from chitosan alone presents low transmittance in the UVC region $(250-280 \mathrm{~nm})$ on the ground of the existence of double bond $(\mathrm{C}=\mathrm{O})$ in remaining chitin after the deacetylation [44]. It was also found that about $90 \%$ light in visible region $(400-800 \mathrm{~nm})$ transmitted though control chitosan film meanwhile the chitosan incorporated with 0.4-1.2\% $(v / v)$ PBLO presented the light transmittance of $70 \%$ in this band. Interestingly, the light transmittance of film formulation made from chitosan containing $0.4 \%(v / v)$ and $1 \%(v / v)$ PBLO was near zero in the region of UVC $(250-280 \mathrm{~nm})$ and UVB $(280-320 \mathrm{~nm})$ and enlarged to UVA $(320-400 \mathrm{~nm})$ with $1.2 \%(v / v)$ incorporated-PBLO. This is due to UV absorbance of phenolic compounds bearing hydroxyl groups conjugated aromatic rings. Similar behavior was also documented as combining chitosan and turmeric extract (mainly composed curcuminoids) which acted as UV absorber due to aromatic groups in the curcuminoids [6]. It can be therefore concluded that film made from chitosan and PBLO can completely block the UV light without significantly reducing the see-through character of food packaging material, which was improved as compared to chitosan film incorporated with Piper betle Linn leaf extract in our previous report [23]. 


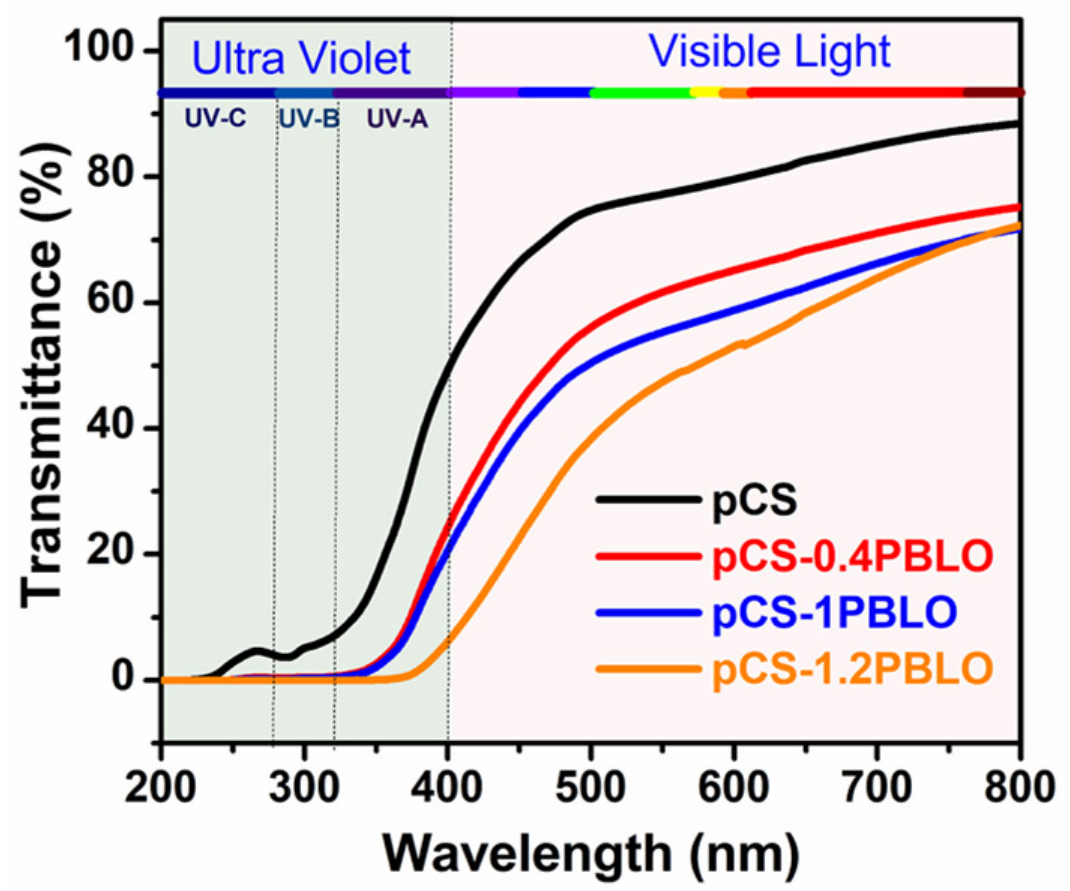

Figure 5. UV-Vis analyses of the pCS, pCS-0.4PBLO, pCS-1PBLO, and pCS-1.2PBLO.

\subsection{Mechanical Behavior}

Sufficient mechanical property of edible films makes an important contribution to protect the integrity of packaging materials during storage and transportation. The tensile strength (Ts), elongation at break $(\mathrm{Eb})$, and elastic modulus (Em) of chitosan-based blend films were recorded at 15.26 $\mathrm{MPa}, 17.49 \%$, and 111.96 $\mathrm{MPa}$, respectively (Table 1). The incorporated-PBLO caused a considerable decrease in Ts (15.26-5.42 MPa) and Em (111.96-25.95 MPa). This behavior is likely due to the presence of oil droplets as observed in SEM images, hindering and interfering chain-chain interaction in chitosan resulting in discontinuities in polymeric chains and thus allowing decreasing fracture resistance and stiff of blend film. Furthermore, the weak inter-molecular interaction between chitosan and PBLO which may partially alter powerful chain-chain interactions [45]. Notably, the film made from chitosan and PBLO became more flexible and mobile evidenced by increasing elongation at break (17-25\%) compared to the film without PBLO. This behavior was partially due to the presences of lipid droplets in film matrix which hinder polymer chain-chain interaction and result in flexible domains in film [46]. Furthermore, phenolic components interacted with chitosan functional groups and weaken the intra molecular forces among polymeric chains resulting in the increment in mobility and flexibility of chitosan film [45]. Another possible explanation due to the presence of emulsifier like Tween 80, importantly contributed to plasticizing effect as synergistic effect between glycerol surfactants with small molecules which could stay between polymeric chains and increase the chain mobility [47]. It was found that the film containing chitosan and PBLO offered more flexibility and mobility in comparison with chitosan/Piper betle Linn extract [23]. Similar findings were reported based on the addition of thyme and clove essential oil into chitosan film [48] and Origanum vulgare L. essential oil into gelatin-chitosan [42] that induced a reduction in Ts although a significant increase in Eb was observed. In contrast, the film made from chitosan incorporated cinnamon essential oil [16], and Apricot (Prunus armeniaca) kernel essential oil [22] presented an increase in Ts and decrease in Eb compared to chitosan alone. Whereas other essential oils such as Perilla frutescens (L.) Britt. essential oil [19], basil essential oil [18], Zataria multiflora Boiss essential oil [17] caused a significant reduction in both $\mathrm{Ts}$ and $\mathrm{Eb}$. These differences as essential oils were added into simple chitosan film [17-19] on mechanical behavior may be mainly due to different kinds and components contained in essential oil, testing conditions as well as emulsifying agents [19]. 
In general, the addition of PBLO into chitosan resulted in more flexible and mobile blend films as merit for food packaging material.

\subsection{Swelling Degree}

The swelling index is a crucial parameter because it is closely related to the integrity of food packaging materials in water media. The swelling progress of chitosan film is due to hydrophilic amino groups which interact with water molecules via hydrogen bonding. Then, the diffusion of water into polymeric matrix resulting making polymer chain relaxed and hydrated therefore leading to expansion in whole polymer network before degradation [49,50]. The degree of swelling of control chitosan film after $24 \mathrm{~h}$ immersed in water was recorded at 50\% (Table 2). All PBLO incorporated chitosan films show higher swelling degree compared to control chitosan. This result is coincided with XRD analyses as the addition of PBLO may convert semi-crystalline in chitosan film toward more amorphous structure. Therefore, the swelling index increased progressively as the incorporated PBLO content augmented. This is opposite with chitosan film incorporated with Piper betle Linn leaf extract in our previous report [23]. The uptrend was likely due to the formation of chemical interaction between functional groups $\left(-\mathrm{OH},-\mathrm{NH}_{2}\right)$ of chitosan and high molecular phenolic groups in PBLO that exerts the partial disruption in polymeric network during $24 \mathrm{~h}$ swelling test [17].

Table 2. The swelling degree and mechanical properties of pCS, pCS-0.4PBLO, pCS-1PBLO, and pCS-1.2PBLO.

\begin{tabular}{ccccc}
\hline Sample Codes & Tensile Strength (MPa) & Elongation at Break (\%) & Elastic Modulus (MPa) & Swelling Degree (\%) \\
\hline pCS & $15.26 \pm 0.38$ & $17.49 \pm 1.09$ & $111.96 \pm 13.31$ & $50.10 \pm 2.56$ \\
pCS-0.4PBLO & $11.98 \pm 0.41$ & $24.97 \pm 0.88$ & $51.00 \pm 1.48$ & $52.57 \pm 3.01$ \\
pCS-1PBLO & $7.71 \pm 0.36$ & $20.62 \pm 0.88$ & $32.16 \pm 2.85$ & $62.05 \pm 4.50$ \\
pCS-1.2PBLO & $5.42 \pm 0.40$ & $17.06 \pm 1.06$ & $25.95 \pm 1.58$ & $70.54 \pm 2.66$ \\
\hline
\end{tabular}

\subsection{Antibacterial Activity}

The antibacterial activities of films were tested by using agar diffusion and liquid incubation methods $[25,26]$. The bacterial viability levels were evaluated using the inhibition diameters of $\geq 28 \mathrm{~mm}, 16-28 \mathrm{~mm}, 12-16 \mathrm{~mm}$, and $\leq 12 \mathrm{~mm}$ for the strong, moderate, mild, and no activities, respectively [51]. As shown in Figure 6, the pCS-PBLO films were evaluated as moderate activities against the E. coli, P. aeruginosa, and S. typhi, except the S. aureus, in which the $S$. typhi was most vulnerable. In addition, the inhibition activity significantly increased in accordance with the increase of the PBLO from $0.4 \%$ to $1 \%(v / v)$. However, the PBLO at concentration of $1.2 \%(v / v)$ did not reveal further increased inhibition efficiency. In contrast, no inhibition zone was observed with the control pCS (Figure S1). This result is accordance with previous reports that the antibacterial activity of chitosan in solid form was negligible because only bacteria directly exposing with active sites were inhibited [16,42]. Similar finding showed that the eugenol, mainly consisted in PBLO, may disrupt the cytoplasmic membrane of $S$. typhi and rise the permeability in bacterial cell [52]. The cell death was resulted from the ion leakage and loss of intracellular proteins. The compactness in polymeric network of pCS-PBLO film may hinder the exposure between bacterial cells and phenolic molecular [16,53]. 


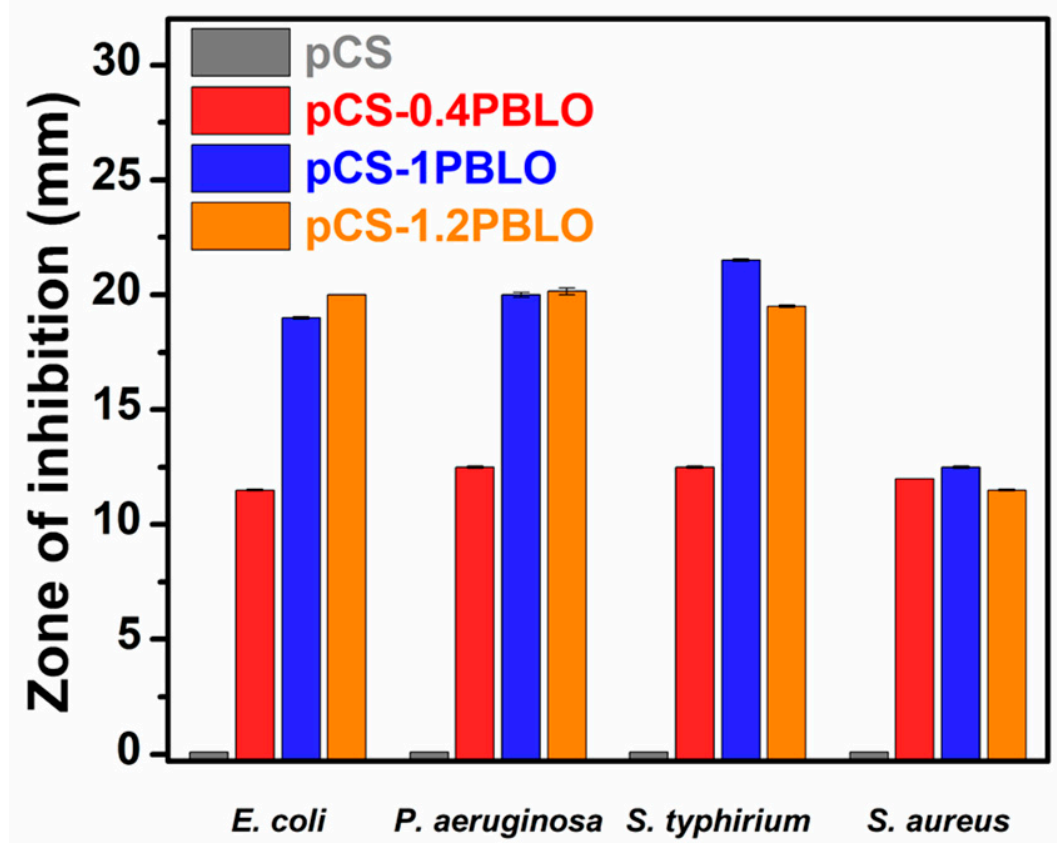

Figure 6. The antibacterial activity of pCS, pCS-0.4PBLO, pCS-1PBLO, and pCS-1.2PBLO against $S$. auereus, E. coli, P. aeruginosa, and S. typhimurium.

Liquid inoculation tests showed that inhibition activities of the pCS-PBLO to E. coli strain was observed at all tested-PBLO concentrations of $0.4 \%, 1 \%$, and $1.2 \%$ (Table 3, Figure S2). However, at low PBLO concentration of $0.4 \%$, the number of bacteria increased after $8 \mathrm{~h}$ of co-inoculation. Interestingly, at PBLO concentration of $1.2 \%$, bacteria were killed after $24 \mathrm{~h}$ of co-inoculation. It found that the antibacterial activity of CS-PBLO film was lower than film containing Piper betle Linn extract [23], which was due to the composition of volatile phenolic compound during oil preparation process. In general, the addition of PBLO significantly improved the antibacterial activity of control chitosan film. These results indicated that the PBLO can be used as an antibacterial agent in producing the effective food packaging film products.

Table 3. Results of time-dependent assays for E. coli.

\begin{tabular}{cccccc}
\hline \multirow{2}{*}{ Sample Codes } & \multicolumn{5}{c}{ Total Colony Forming Units (CFU/mL) } \\
\cline { 2 - 6 } & $\mathbf{0 ~ h}$ & $\mathbf{4} \mathbf{h}$ & $\mathbf{8} \mathbf{h}$ & $\mathbf{1 1} \mathbf{h}$ & $\mathbf{2 4} \mathbf{h}$ \\
\hline pCS & $7.50 \times 109$ & $8.30 \times 109$ & GO & GO & GO \\
pCS-0.4PBLO & $7.80 \times 109$ & $7.40 \times 109$ & $5.70 \times 109$ & $6.20 \times 109$ & $12.30 \times 109$ \\
pCS-1PBLO & $7.60 \times 109$ & $5.45 \times 109$ & $4.65 \times 109$ & $2.35 \times 109$ & $2.00 \times 108$ \\
pCS-1.2PBLO & $7.50 \times 109$ & $4.65 \times 109$ & $1.45 \times 109$ & $4.00 \times 108$ & ++++ \\
\hline (++++): strong inhibition; GO: growth over. & & &
\end{tabular}

\subsection{Antioxidant Activity}

In addition to bactericidal activity, PBLO as an antioxidant source incorporated with chitosan film may scavenge the free radicals preventing the oxidation of nutritional components and food deterioration. The antioxidant activity of pCS-PBLO films was evaluated through the half maximal inhibitory concentration $\left(\mathrm{IC}_{50}\right)$ which was determined as the concentration of sample required to scavenge $50 \%$ of DPPH radicals. The lower the $\mathrm{IC}_{50}$ value is, the stronger the antioxidant activity is. Herein, $\mathrm{IC}_{50}$ values of films containing $0.4,1.0$, and $1.2 \%(v / v)$ PBLO were resulted in $48.43,44.86$, and $42.49 \mu \mathrm{g} / \mathrm{mL}$, indicating that antioxidant activity of resultant films increased with increasing incorporated PBLO concentration. The phenolic compound bearing - $\mathrm{OH}$ groups in PBLO may contribute to antioxidant mechanism as they scavenge $\mathrm{DPPH} \cdot$ by donating either electron or hydrogen 
radical to free radical [54]. The $\mathrm{IC}_{50}$ index was not documented for control chitosan film. Although active amino groups presenting in chitosan structure can react with free radical, the inhibitory efficiency of neat chitosan to DPPH was lower than $50 \%$ [55]. It can be observed the antioxidant activity of chitosan film was improved by the incorporation of PBLO; however, this property was lower as compared to that in the film containing Piper betle Linn extract [23]. These results revealed that PBLO containing chitosan films hold great antibacterial and antioxidant activities making them ideally suitable for food packaging film.

\subsection{Preservative Application}

The king orange, a variety of citrus fruit from Vietnam, was chosen for the test because it abundantly contained high nutritional values, especially rich in vitamin $C$. The appearance of king oranges with and without chitosan-based coatings, stored at $25{ }^{\circ} \mathrm{C}$ for 2 weeks were showed (Figure 7). The uncoated samples (control) were utilized to compare with coated king oranges. The bright green rind is observed for control sample while coated oranges reveals shinier and bright green rind surface on the first day. However, the rind of control sample moved to light yellow in color after storage 5 days but those do not occur for coated oranges. After 10 days, the bright yellow color is clearly viewed in control and chitosan coating on the orange surface begins to peel off. Interestingly, pCS-0.4PBLO coated orange still keep bright green and shiny skin after 10 days and up to two weeks. This is supported by the fact that higher work of adhesion and spreading coefficient of pCS-0.4PBLO solution over orange skin as compared to chitosan based coating liquids (Table S2). For cross-section images, the dense and compact texture are obviously observed for the king orange coated by chitosan and chitosan-0.4PBLO solution.

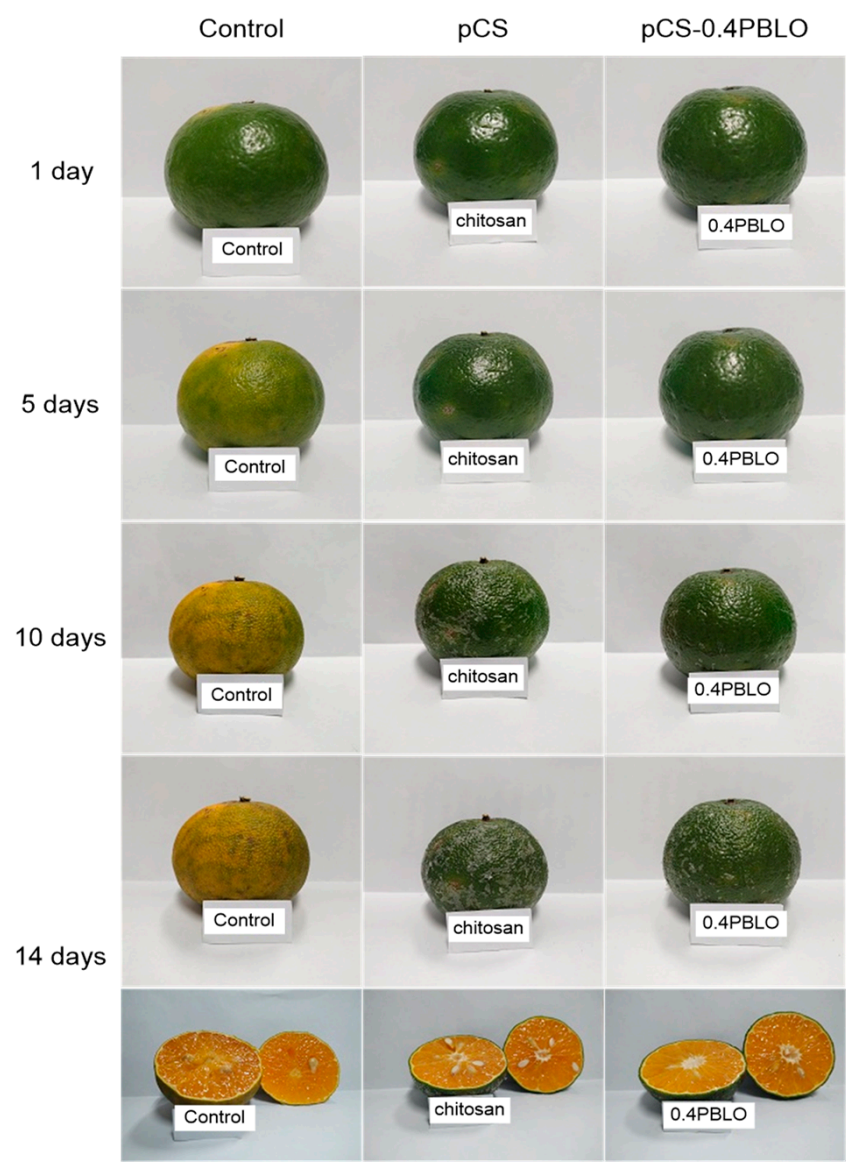

Figure 7. The visual appearance of king oranges with and without coating stored at $25^{\circ} \mathrm{C}$ for two weeks. 


\section{Conclusions}

The present work reports the successful incorporation of Piper betle Linn oil in chitosan film (pCS-PBLO film) to produce potential active food packaging material. The microstructure of the pCS-PBLO film exhibited discontinuous and heterogeneous appearance by the presence of oil droplets on the film surface. Furthermore, the inter-molecular interaction among functional groups in chitosan and Piper betle Linn oil was confirmed by FTIR, XRD, and TGA analyses. The mechanical behavior and swelling degree were directly affected by the incorporation of PBLO. The pCS-PBLO film revealed the antibacterial and antioxidant activity based on phenolic compounds such as acetyleugenol, eugenol, 4-allyl-1,2-diacetoxybenzen, chavicol acetate in PBLO components; however, the bioactivity of resultant films was lower as compared to that in chitosan film containing Piper betle Linn extract in our previous report. Moreover, the great UV-barrier property and strong antioxidant activity was the light of the pCS-PBLO film. In particularly, the pCS-PBLO film may protect the shelf life of king oranges from the food deterioration for up to two weeks, suggesting that the film can be proposed for effective food packaging application.

Supplementary Materials: The following are available online at https: / www.mdpi.com/2079-6 412/11/3/351/s1, Figure S1: Inhibitory effects of PBLLE incorporated chitosan films against the growth of Staphylococcus aureus, Salmonella Typhimurium, Escherichia coli, and Pseudomonas aeruginosa were observed via real photos taken after $24 \mathrm{~h}$ exposure, Figure S2: Inhibitory effects of PBLLE incorporated chitosan films against the growth of Escherichia coli was observed via real photos taken after $0 \mathrm{~h}, 4 \mathrm{~h}, 8 \mathrm{~h}, 11 \mathrm{~h}$ and $24 \mathrm{~h}$ exposure Table S1: Degradative temperature and mass loss of pCS, pCS-0.4PBLO, pCS-1PBLO, and pCS-1.2PBLO, Table S2: Surface tension, work of adhension, and spreading coefficient of chitosan solution with and without PBLO.

Author Contributions: T.T.N.: Conceptualization, Data curation, Formal analysis, Funding acquisition, Investigation, Methodology, Project administration, Visualization, Writing-original draft; T.-T.T.N.: Formal analysis; T.V.T.: Methodology; L.V.T.: Data curation, Methodology; L.T.D.: Data curation, Methodology; V.T.T.: Writing-original draft, Writing-review \& editing. All authors have read and agreed to the published version of the manuscript.

Funding: The study was supported by The Youth Incubator for Science and Technology Program, managed by Youth Development Science and Technology Center-Ho Chi Minh Communist Youth Union and Department of Science and Technology of Ho Chi Minh City, the contract number is “26/2019/HĐ-KHCN-VU'".

Institutional Review Board Statement: Not applicable.

Informed Consent Statement: Not applicable.

Data Availability Statement: Not applicable.

Conflicts of Interest: The authors declare that they have no known competing financial interests or personal relationships that could have appeared to influence the work reported in this paper.

\section{References}

1. Reddy, S. Plastic Pollution Affects Sea Life Throughout the Ocean. In Proceedings of the Preventing Ocean Plastics. The Pew Charitable Trusts, New Zealand, September 2018. Available online: https:/ / www.pewtrusts.org/en/research-and-analysis/ articles /2018/09/24/plastic-pollution-affects-sea-life-throughout-the-ocean (accessed on 5 February 2021).

2. Ferreira, A.R.V.; Alves, V.D.; Coelhoso, I.M. Polysaccharide-based membranes in food packaging applications. Membranes 2016, 6, 22. [CrossRef]

3. Atarés, L.; Chiralt, A. Essential oils as additives in biodegradable films and coatings for active food packaging. Trends Food Sci. Technol. 2016, 48, 51-62. [CrossRef]

4. Nguyen, T.T.; Thi Dao, U.T.; Thi Bui, Q.P.; Bach, G.L.; Ha Thuc, C.N.; Ha Thuc, H. Enhanced antimicrobial activities and physiochemical properties of edible film based on chitosan incorporated with Sonneratia caseolaris (L.) Engl. leaf extract. Prog. Org. Coat. 2020, 140, 105487. [CrossRef]

5. Souza, V.G.L.; Fernando, A.L.; Pires, J.R.A.; Rodrigues, P.F.; Lopes, A.A.S.; Fernandes, F.M.B. Physical properties of chitosan films incorporated with natural antioxidants. Ind. Crops Prod. 2017, 107, 565-572. [CrossRef]

6. Kalaycıŏlu, Z.; Torlak, E.; Akın-Evingür, G.; Özen, İ.; Erim, F.B. Antimicrobial and physical properties of chitosan films incorporated with turmeric extract. Int. J. Biol. Macromol. 2017, 101, 882-888. [CrossRef] 
7. Umar, R.A.; Zahary, M.N.; Ismail, S.; Rohin, M.A.K. Chemical Composition and The Potential Biological Activities Of Piper Betel-A Review. Malaysian J. Appl. Sci. 2018, 3, 1-8.

8. Kanjwani, D.G.; Marathe, T.P.; Chiplunkar, S.V.; Sathaye, S.S. Evaluation of immunomodulatory activity of methanolic extract of Piper betel. Scand. J. Immunol. 2008, 67, 589-593. [CrossRef]

9. Muruganandam, L.; Krishna, A.; Reddy, J.; Nirmala, G.S. Optimization studies on extraction of phytocomponents from betel leaves. Resour. Technol. 2017, 3, 385-393. [CrossRef]

10. Das, S.; Parida, R.; Sriram Sandeep, I.; Nayak, S.; Mohanty, S. Biotechnological intervention in betelvine (Piper betle L.): A review on recent advances and future prospects. Asian Pac. J. Trop. Med. 2016, 9, 938-946. [CrossRef]

11. Prakash, B.; Shukla, R.; Singh, P.; Kumar, A.; Mishra, P.K.; Dubey, N.K. Efficacy of chemically characterized Piper betle L. essential oil against fungal and aflatoxin contamination of some edible commodities and its antioxidant activity. Int. J. Food Microbiol. 2010, 142, 114-119. [CrossRef]

12. Boudouaia, N.; Bengharez, Z.; Jellali, S. Preparation and characterization of chitosan extracted from shrimp shells waste and chitosan film: Application for Eriochrome black T removal from aqueous solutions. Appl. Water Sci. 2019, 9, 1-12. [CrossRef]

13. Islam, S.; Bhuiyan, M.A.R.; Islam, M.N. Chitin and chitosan: Structure, properties and applications in biomedical engineering. J. Polym. Environ. 2017, 25, 854-866. [CrossRef]

14. Benhabiles, M.S.; Salah, R.; Lounici, H.; Drouiche, N.; Goosen, M.F.A.; Mameri, N. Antibacterial activity of chitin, chitosan and its oligomers prepared from shrimp shell waste. Food Hydrocoll. 2012, 29, 48-56. [CrossRef]

15. Goy, R.C.; Morais, S.T.B.; Assis, O.B.G. Evaluation of the antimicrobial activity of chitosan and its quaternized derivative on E. Coli and S. aureus growth. Rev. Bras. Farmacogn. 2016, 26, 122-127. [CrossRef]

16. Ojagh, S.M.; Rezaei, M.; Razavi, S.H.; Hosseini, S.M.H. Development and evaluation of a novel biodegradable film made from chitosan and cinnamon essential oil with low affinity toward water. Food Chem. 2010, 122, 161-166. [CrossRef]

17. Moradi, M.; Tajik, H.; Razavi Rohani, S.M.; Oromiehie, A.R.; Malekinejad, H.; Aliakbarlu, J.; Hadian, M. Characterization of antioxidant chitosan film incorporated with Zataria multiflora Boiss essential oil and grape seed extract. LWT Food Sci. Technol. 2012, 46, 477-484. [CrossRef]

18. Hemalatha, T.; UmaMaheswari, T.; Senthil, R.; Krithiga, G.; Anbukkarasi, K. Efficacy of chitosan films with basil essential oil: Perspectives in food packaging. J. Food Meas. Charact. 2017, 11, 2160-2170. [CrossRef]

19. Zhang, Z.J.; Li, N.; Li, H.Z.; Li, X.J.; Cao, J.M.; Zhang, G.P.; He, D.L. Preparation and characterization of biocomposite chitosan film containing Perilla frutescens (L.) Britt. essential oil. Ind. Crops Prod. 2018, 112, 660-667. [CrossRef]

20. Hafsa, J.; ali Smach, M.; Ben Khedher, M.R.; Charfeddine, B.; Limem, K.; Majdoub, H.; Rouatbi, S. Physical, antioxidant and antimicrobial properties of chitosan films containing Eucalyptus globulus essential oil. LWT Food Sci. Technol. 2016, 68, 356-364. [CrossRef]

21. Mahdavi, V.; Hosseini, S.E.; Sharifan, A. Effect of edible chitosan film enriched with anise (Pimpinella anisum L.) essential oil on shelf life and quality of the chicken burger. Food Sci. Nutr. 2018, 6, 269-279. [CrossRef]

22. Priyadarshi, R.; Kumar, B.; Deeba, F.; Kulshreshtha, A.; Negi, Y.S. Chitosan films incorporated with Apricot (Prunus armeniaca) kernel essential oil as active food packaging material. Food Hydrocoll. 2018, 85, 158-166. [CrossRef]

23. Thuong, N.T.; Ngoc Bich, H.T.; Thuc, C.N.H.; Quynh, B.T.P.; Minh, L.V. Preparation and characterization of Piper betle Linn. leaf extract incorporated chitosan films as potential active food packaging materials. ChemistrySelect 2019, 4, 8150-8157. [CrossRef]

24. ASTM G40-15 Standard Terminology Relating to Wear and Erosion; ASTM: West Conshohocken, PA, USA, 2015.

25. Peng, Y.; Li, Y. Combined effects of two kinds of essential oils on physical, mechanical and structural properties of chitosan films. Food Hydrocoll. 2014, 36, 287-293. [CrossRef]

26. Jin, T.; Liu, L.; Zhang, H.; Hicks, K. Antimicrobial activity of nisin incorporated in pectin and polylactic acid composite films against Listeria monocytogenes. Int. J. Food Sci. Technol. 2009, 44, 322-329. [CrossRef]

27. Brand-Williams, W.; Cuvelier, M.E.; Berset, C. Use of a free radical method to evaluate antioxidant activity. LWT-Food Sci. Technol. 1995, 28, 25-30. [CrossRef]

28. Soradech, S.; Nunthanid, J.; Limmatvapirat, S.; Luangtana-anan, M. Utilization of shellac and gelatin composite film for coating to extend the shelf life of banana. Food Control 2017, 73, 1310-1317. [CrossRef]

29. Hebbar, R.S.; Isloor, A.M.; Ismail, A.F. Contact Angle Measurements. In Membrane Characterization; Hilal, N., Matsuura, T., Oatley-Radcliffe, D., Fauzi Ismail, A., Eds.; Elsevier Inc.: Amsterdam, The Netherlands, 2017; Volume 122, pp. 219-255. [CrossRef]

30. Madhumita, M.; Guha, P.; Nag, A. Extraction of betel leaves (Piper betle L.) essential oil and its bio-actives identification: Process optimization, GC-MS analysis and anti-microbial activity. Ind. Crops Prod. 2019, 138, 111578. [CrossRef]

31. Bagamboula, C.F.; Uyttendaele, M.; Debevere, J. Inhibitory effect of thyme and basil essential oils, carvacrol, thymol, estragol, linalool and p-cymene towards Shigella sonnei and S. flexneri. Food Microbiol. 2004, 21, 33-42. [CrossRef]

32. Haghighi, H.; Biard, S.; Bigi, F.; De Leo, R.; Bedin, E.; Pfeifer, F.; Siesler, H.W.; Licciardello, F.; Pulvirenti, A. Comprehensive characterization of active chitosan-gelatin blend films enriched with different essential oils. Food Hydrocoll. 2019, 95, 33-42. [CrossRef]

33. Kaya, M.; Ravikumar, P.; Ilk, S.; Mujtaba, M.; Akyuz, L.; Labidi, J.; Salaberria, A.M.; Cakmak, Y.S.; Erkul, S.K. Production and characterization of chitosan based edible films from Berberis crataegina's fruit extract and seed oil. Innov. Food Sci. Emerg. Technol. 2018, 45, 287-297. [CrossRef] 
34. Kadam, D.; Shah, N.; Palamthodi, S.; Lele, S.S. An investigation on the effect of polyphenolic extracts of Nigella sativa seedcake on physicochemical properties of chitosan-based films. Carbohydr. Polym. 2018, 192, 347-355. [CrossRef]

35. Rhim, J.W.; Hong, S.I.; Park, H.M.; Ng, P.K.W. Preparation and characterization of chitosan-based nanocomposite films with antimicrobial activity. J. Agric. Food Chem. 2006, 54, 5814-5822. [CrossRef]

36. Sayyar, S.; Murray, E.; Thompson, B.C.; Chung, J.; Officer, D.L.; Gambhir, S.; Spinks, G.M.; Wallace, G.G. Processable conducting graphene/chitosan hydrogels for tissue engineering. J. Mater. Chem. B 2015, 3, 481-490. [CrossRef]

37. Sun, L.; Sun, J.; Chen, L.; Niu, P.; Yang, X.; Guo, Y. Preparation and characterization of chitosan film incorporated with thinned young apple polyphenols as an active packaging material. Carbohydr. Polym. 2017, 163, 81-91. [CrossRef]

38. Go, E.J.; Song, K. Bin Effect of java citronella essential oil addition on the physicochemical properties of Gelidium corneumchitosan composite films. Food Sci. Biotechnol. 2020, 29, 909-915. [CrossRef]

39. Jahed, E.; Khaledabad, M.A.; Almasi, H.; Hasanzadeh, R. Physicochemical properties of Carum copticum essential oil loaded chitosan films containing organic nanoreinforcements. Carbohydr. Polym. 2017, 164, 325-338. [CrossRef]

40. Nguyen, L.T.T.; Nguyen, T.T.; Nguyen, H.N.; Bui, Q.T.P. Simultaneous determination of active compounds in Piper betle Linn. leaf extract and effect of extracting solvents on bioactivity. Eng. Rep. 2020, 2, 2-9. [CrossRef]

41. Sánchez-González, L.; Vargas, M.; González-Martínez, C.; Chiralt, A.; Cháfer, M. Characterization of edible films based on hydroxypropylmethylcellulose and tea tree essential oil. Food Hydrocoll. 2009, 23, 2102-2109. [CrossRef]

42. Hosseini, S.F.; Rezaei, M.; Zandi, M.; Farahmandghavi, F. Bio-based composite edible films containing Origanum vulgare L. essential oil. Ind. Crops Prod. 2015, 67, 403-413. [CrossRef]

43. Intawiwat, N.; Pettersen, M.K.; Rukke, E.O.; Meier, M.A.; Vogt, G.; Dahl, A.V.; Skaret, J.; Keller, D.; Wold, J.P. Effect of different colored filters on photooxidation in pasteurized milk. J. Dairy Sci. 2010, 93, 1372-1382. [CrossRef]

44. Azofeifa, D.E.; Arguedas, H.J.; Vargas, W.E. Optical properties of chitin and chitosan biopolymers with application to structural color analysis. Opt. Mater. 2012, 35, 175-183. [CrossRef]

45. Yang, L.; Paulson, A.T. Effects of lipids on mechanical and moisture barrier properties of edible gellan film. Food Res. Int. 2000, 33, 571-578. [CrossRef]

46. Butnaru, E.; Stoleru, E.; Brebu, M.A.; Darie-Nita, R.N.; Bargan, A.; Vasile, C. Chitosan-based bionanocomposite films prepared by emulsion technique for food preservation. Materials 2019, 12, 373. [CrossRef]

47. Ghanbarzadeh, B.; Almasi, H. Physical properties of edible emulsified films based on carboxymethyl cellulose and oleic acid. Int. J. Biol. Macromol. 2011, 48, 44-49. [CrossRef]

48. Hosseini, M.H.; Razavi, S.H.; Mousavi, M.A. Antimicrobial, physical and mechanical properties of chitosan-based films incorporated with thyme, clove and cinnamon essential oils. J. Food Process. Preserv. 2009, 33, 727-743. [CrossRef]

49. Ren, D.; Yi, H.; Wang, W.; Ma, X. The enzymatic degradation and swelling properties of chitosan matrices with different degrees of N-acetylation. Carbohydr. Res. 2005, 340, 2403-2410. [CrossRef]

50. Baskar, D.; Sampath Kumar, T.S. Effect of deacetylation time on the preparation, properties and swelling behavior of chitosan films. Carbohydr. Polym. 2009, 78, 767-772. [CrossRef]

51. Semeniuc, C.A.; Pop, C.R.; Rotar, A.M. Antibacterial activity and interactions of plant essential oil combinations against Grampositive and Gram-negative bacteria. J. Food Drug Anal. 2017, 25, 403-408. [CrossRef]

52. Devi, K.P.; Nisha, S.A.; Sakthivel, R.; Pandian, S.K. Eugenol (an essential oil of clove) acts as an antibacterial agent against Salmonella typhi by disrupting the cellular membrane. J. Ethnopharmacol. 2010, 130, 107-115. [CrossRef]

53. Siripatrawan, U.; Vitchayakitti, W. Improving functional properties of chitosan films as active food packaging by incorporating with propolis. Food Hydrocoll. 2016, 61, 695-702. [CrossRef]

54. Alavi Rafiee, S.; Farhoosh, R.; Sharif, A. Antioxidant Activity of Gallic Acid as Affected by an Extra Carboxyl Group than Pyrogallol in Various Oxidative Environments. Eur. J. Lipid Sci. Technol. 2018, 120, 1-8. [CrossRef]

55. Talón, E.; Trifkovic, K.T.; Nedovic, V.A.; Bugarski, B.M.; Vargas, M.; Chiralt, A.; González-Martínez, C. Antioxidant edible films based on chitosan and starch containing polyphenols from thyme extracts. Carbohydr. Polym. 2017, 157, 1153-1161. [CrossRef] 